\title{
Potreba i mogućnost evangelizacije putem interneta
}

\author{
Danijel Časni \\ Biblijski institut, Zagreb \\ dcasni@bizg.hr
}

UDK: 2-766:316-774

Izvorni znanstveni članak

https://doi.org/10.32862/k1.13.1.3

\section{Sažetak}

Evangelizacija putem interneta, u današnjem društvu tehnološkog napretka, primjeren je alat za naviještanje Radosne vijesti. Upotrebom interneta, Crkva komunicira na lokalnoj razini u svojoj mjesnoj crkvi, ali i šire na globalnoj razini, ostvarujući pritom svoje poslanje naviještanja Evanđelja „svim narodima". U članku se govori o potrebi upotrebe interneta i društvenih mreža u službi evangelizacije, kao medija za prijenos poruke spasenja i nade u Isusu Kristu. Analizom upotrebe interneta u evanđeoskim crkvama u Hrvatskoj, pruža se uvid u trenutno stanje i mogućnost učinkovitijeg korištenja novih medija u naviještanju Radosne vijesti.

\section{Uvod}

U Evanđelju po Mateju 9,16-18 čitamo riječi koje bismo mogli primijeniti na današnje vrijeme i metode evangelizacije. "I ne ulijeva se novo vino u stare mješine. Inače se mješine proderu, vino prolije, a mješine propadnu. Nego, novo se vino ulijeva u nove mješine pa se oboje sačuva." Pitanje je postaje li u današnjem pluralističkom sekulariziranom društvu internet odgovarajuće sredstvo za evangelizaciju i naviještanje Radosne vijesti, bez obzira na to koristi li mjesna crkva nove medije ili ne? Osvrnemo li se oko sebe i pogledamo mlađu generaciju kako koristi moderne društvene medije u međusobnoj komunikaciji i informiranosti, sigurno ćemo primijetiti da današnji mediji imaju značajnu ulogu u životima tih pojedinaca. Isto tako, ako želimo ostvariti veću prisutnost u društvu, prihvatit ćemo 
neke od modernih društvenih platformi koje se danas nude, poput Facebooka, Twittera, Google+, Linkedina, blogova, internet chat sobe ili nekih drugih načina na koji možemo ostvariti socijalni kontakt.

\section{Novi mediji i društvo}

Internet, kao medij današnjice, više nije ograničen samo na mlade već je prisutan $\mathrm{u}$ svim generacijama. Zastupljeniji je kod mlađih, ali iz dana u dan raste broj korisnika starije populacije. Polako, ali sigurno internet groznica prodire u sve slojeve društva.

Internet je sredstvo komunikacije pomoću kojeg Crkva može bolje prezentirati svoje djelovanje, misiju i viziju u društvu. Putem interneta propovijedana i pisana Božja riječ, molitva, duhovna misao i općenito Evanđelje može doprijeti do brojnih ljudi. U mjesnim crkvama je obično takva praksa da se najčešće koriste oni komunikacijski kanali koji su za pojedine crkvene djelatnike uobičajeni. To su oni klasični kanali pomoću kojih su pojedinci došli do spoznaje Radosne vijesti, poput radija ili tiskovina. Međutim, to što su neki komunikacijski kanali bili učinkoviti 80-ih godina prošloga stoljeća, ne znači da su isto tako učinkoviti i danas. Potrebno je sagledati koja je to ciljna skupina kojoj želimo približiti Evanđelje te otkriti način koji će upravo za tu skupinu biti najučinkovitiji.

Sve je više onih koji smatraju da je listanje novina na vlastitom mobilnom uređaju puno prihvatljivije, lakše i jeftinije od tiskanih novina. U prošlosti su novine kao sredstvo javnog informiranja imale važnu ulogu u društvu. Danas se mladi s pravom pitaju: “Tko uopće čita tiskovine?” Komparativna je analiza u disertaciji Franje Maletića $(2008,289)$ pokazala da je na svjetskoj razini čitalačka publika dnevnih tiskanih novina u prosjeku starija od pedeset godina. Iz analize proizlazi da se u sljedećih deset godina očekuje zaustavljanje tiskarske proizvodnje i pronalaženje novih kanala komunikacije na tržištu dnevnih novina. Usvajanjem novih oblika komunikacije i upotrebom novih medija u naviještanju Evanđelja može se doprijeti do mlađe generacije na njima primjeren način. Poznavanjem suvremenog društva u kojemu mladi žive pridonosi učinkovitosti evangelizacije. Nesigurnost i relativnost je značajna karakteristika današnjeg društva i svijeta u cjelini. Sumnjaju svi u sve pa čak i djeca i odrasli. Sve manje se vjeruje, a sve više propitkuje. Sve se dovodi u pitanje: od znanstvenih metoda do temeljnih egzistencijalnih uporišta. Nema više potpune jasnoće. Nema apsoluta.

Postmodernizam sa svojim obilježjima značajno je definirao životni stil i ponašanje mladih koji tek otkrivaju, oblikuju i usvajaju vlastiti svjetonazor. Naglasak je na sadašnjosti koja nije uznemirena metafizičkim pitanjima, već sadašnjosti koja se sastoji u zadovoljavanju trenutnih želja i potreba. Postmodernistička obilježja karakterizirana su gubitkom sigurnosti, napuštanjem čvrstih temelja i odlaskom u 
nepoznato. Kako u tako nesigurnom i gotovo kaotičnom svijetu današnjim mladim ljudima ponuditi smisao i vjeru u budućnost? Kako im približiti odgovornu slobodu? Slobodu koju daje Krist? Kako ih oduševiti za život i pružiti im nadu?

Čovjek je tijekom povijesti svoju puninu nalazio u Bogu, u vjeri u Isusa Krista. Nažalost, današnji čovjek ispunjenje čežnje za izgubljenim rajem ne očekuje više od vjere u Boga, nego od znanosti, napretka i tehnologije. U takvu ozračju, vjera se sve više marginalizira i prebacuje isključivo na privatnu razinu.

\section{Novi mediji i evangelizacija}

Crkva je tijekom povijesti vrlo uspješno usvajala nove medije u službi evangelizacije. Tiskarstvo, radio i televizija služili su i još uvijek služe za navještanje Evanđelja. Tiskani mediji omogućili su širenje Evanđelja kao nikada ranije. Radio je toj brzini donio transkontinentalnost, a televizija je uz zvuk donijela i sliku te postala vrlo učinkovit, ali skup medij za prenošenje poruke Evanđelja. Suvremeni mediji, poput interneta i društvenih mreža, omogućuju na najjeftiniji i vrlo kreativan način objedinjenje svih tehničkih mogućnosti dosadašnjih medija. Korištenjem novih medija Crkvi se otvaraju široke mogućnosti u naviještanju evanđelja Gospodina Isusa Krista. Kristovu poruku nade i novog života moguće je trenutno prenijeti velikom broju ljudi. Stoga, ključno je pitanje: na koji način koristiti internet za Božju slavu?

Za učinkovitu evangelizaciju vrlo je značajna dobra komunikacija. Evangelizacija putem interneta je komunikacija Evanđelja i naviještanja Radosne vijesti, poruke spasenja i nade koja pretvara život grešnika u novi ispunjen i prema vječnosti usmjeren život. No poput svake komunikacije, ona ne bi smjela biti prepuštena slučaju. Crkva komunicira s vjernicima, ali i sa širom javnosti. Upotrebom interneta, Crkva komunicira na globalnoj, a ne samo na lokalnoj razini. Današnji mediji poput društvenih mreža omogućavaju slanje i primanje poruka -dvosmjernu komunikaciju, razmjenu stavova, diskusiju, slanje tekstualnih i videoporuka koristeći univerzalni Cyber prostor.

Evangelizacija uključuje cijeli niz napora vezanih uz objavljivanje Radosne vijesti Isusa Krista kako bi se ljudima približila i postala razumljiva ponuda spasenja, oproštenja grijeha i sloboda novog života u Kristu, služeći mu u zajedništvu vjernika u Crkvi. Poruka Evanđelja, uz obraćenje osobe, podrazumijeva i stvaranje učenika koji će predano živjeti, djelovati i pomagati u napretku lokalne zajednice. U Evanđelju po Ivanu 6,35 čitamo da je Isus Krist temelj za širenje Radosne vijesti, odnosno Evanđelja: "Reče im Isus: Ja sam kruh života. Tko dolazi k meni, neće ogladnjeti; tko vjeruje u mene, neće ožednjeti nikada." Stoga, svaki kršćanin treba imati dinamičnu vjeru u uskrslog Krista, koji svojom riječju zahvaća u najskrivenije kutke ljudskog bića i mijenja stanje pojedinca opraštajući grijehe i oslobađajući tereta krivnje pred Bogom. 
Michael Green je naglasio da "Evangelizacija nije ljudska propaganda. U nju je uključen Bog kada je poslao svog jedinorođenog Sina. Isus Krist ga je smatrao tako prioritetnim zadatkom da ga je učinio predmetom svoje posljednje zapovijedi. Duh Sveti je poslan sa ciljem da opremi Crkvu za svjedočenje. Evangeliziranje je djelatan iskaz Božje ljubavi u palom svijetu" $(1979,15)$. Stoga, i Crkva bi trebala biti otvorena i usmjerena s jedne strane na evangelizaciju svojih nominalnih vjernika - ad intra, ali još više na evangelizaciju u društvu u kojem se nalazi - ad extra.

U današnjem globaliziranom svijetu masovnih medija, interneta i društvenih mreža, kršćani i Crkva trebaju koristiti suvremene komunikacijske kanale u navješćivanju Radosne vijesti. Cilj je doprijeti do ljudi koji traže „put i smisao“ za svoj život i uputiti ih na spasenje u Kristu koje ima vječnu vrijednost. Prihvaćanjem Krista za Gospodina i gospodara osobnog života izgrađuje se most između Boga i čovjeka. Rađa se novi život u miru s Bogom. Kristov odraz i suobličavanje s njime u praktičnom životu kršćanina, postaje vidljiv znak pripadnosti Kristovu tijelu Njegovoj Crkvi. Poslanje svakog Kristova učenika je biti „sol i svjetlo“ svijeta. Biti jasan smjerokaz u društvu koji svojim životom i aktivnošću usmjerava na Krista.

U Evanđelju po Mateju 28,19 stoji Isusova zapovijed i evangelizacijski poziv njegovim učenicima: „zato idite i učinite sve narode učenicima mojim“. Radosna vijest o Kristu Spasitelju, koji je donio oproštenje grijeha, upućena je svakome koji u njega vjeruje, bilo Židovu ili poganinu. Tu poruku treba čuti, razumjeti, prihvatiti i po njoj živjeti. Novi mediji omogućuju prijenos poruke, što je inicijalna zadaće evangelizacije. Za rast u vjeri potrebno je stvarno zajedništvo $s$ braćom i sestrama u mjesnoj crkvi. Digitalnim virtualnim odnosom, koji pružaju novi mediji, nezamisliv je razvoj učeništva i duhovnog rasta u vjeri. Stvarni odnos i razmjena duhovnog iskustva u zajednici vjerujućih nema alternative. Duh Sveti svojim djelovanjem prosvjetljuje um grešnika koji počinje razumijevati poruku spasenja. Dar vječnoga života koji grešnik ima u Isusu Kristu potrebno je prihvatiti vjerom. Čovjek svojim grijehom narušuje odnos s Bogom uzrokujući trenutni prekid komunikacije. Ispovijedanjem grijeha i uspostavljanjem odnosa sa svojim Spasiteljem, uspostavlja se veza između Boga i čovjeka. Čovjek više nije sam, već je u zajedništvu s Bogom te postaje Kristov svjedok. Isus je rekao u Evanđelju po Mateju 28,20 da je "s nama u sve dane do kraja svijeta". Ohrabruje činjenica da je Bog uvijek online. On je uvijek tu i odgovara onima koji ga traže.

Upotrebom današnje moderne tehnologije moguće je naviještati Krista do nakraj svijeta, ali je potrebno ohrabriti svakog nanovorođenoga kršćanina da se priključi mjesnoj crkvi i postane učenik koji vjerno nasljeduje Krista. Svjedok Kristov ispunjava se Duhom Svetim, što rezultira htijenjem i djelovanjem na putu naviještanja Evanđelja. U Djelima apostolskim 1,8, Isus je rekao svojim učenicima da će ih osnažiti da budu njegovi svjedoci sa zadaćom dolaska u izgubljene krajeve svijeta: "Ali primit ćete snagu pošto Duh Sveti siđe na vas i bit ćete mi svje- 
doci u Jeruzalemu, u svoj Judeji, u Samariji i sve do kraja zemlje”. Kristov svjedok koristi se svim alatima u naviještanju Evanđelja, što uključuje nove medije.

\section{Društvene mreže}

Postoje četiri osnovne vrste "web mreža": obiteljska, geografska (teritorijalna), strukovna (karijera, obrazovanje) i relacijska (prijateljska). Načelno je mišljenje da su u urbanim sredinama dominantne druge dvije, a u ruralnim sredinama prve dvije. Ovisno o tome o kojoj je skupini riječ, ona će se koristiti jednom ili drugom vrstom društvene mreže. Crkva se u svome radu može koristiti svim vrstama društvenih mreža.

Broj korisnika društvenih mreža eksponencijalno raste iz dana u dan. Stoga, online prisutnost Crkve u digitalnom svijetu od iznimne je važnosti za vjernike. Društveni medij kao što je Facebook može biti učinkovita platforma za evangelizaciju, informiranje o događanjima u Crkvi te alat za razvijanje odnosa između vjernika i svih zainteresiranih. Brojni analitičari su tijekom posljednjih godina upozoravali kako će Facebook doživjeti sudbinu MySpacea te da će postati dosadan i pasti u zaborav. Međutim, to se nije dogodilo. Broj korisnika je konstantno rastao, a podaci o broju korisnika koje su objavili iz Facebooka (sječanj 2015), pokazuju da je broj korisnika 2014. godine prerastao ukupan broj stanovnika Kine koja je najmnogoljudnija zemlja svijeta. Prema podacima koji su objavljeni na Huffington Postu (Stenovec 2015), broj korisnika koji posjećuje Facebook mrežu barem jednom mjesečno, krajem 2014. godine je iznosio preko 1,39 milijardi, dok broj stanovnika u Kini u isto vrijeme iznosio 1,36 milijardi. Facebook je 2014. godine zabilježio porast korisnika koji dnevno posjećuju ovu društvenu mrežu za 18 posto, odnosno više od 890 milijuna (Facebook, siječanj 2015), odnosno gotovo dvostruko više od broja stanovnika Europe, koji je 2018. godine iznosio 513 milijuna (Eurostat, srpanj 2018). Prema podacima iz trećeg kvartala 2018. godine (Statistica 2018), broj korisnika Facebooka u svijetu iznosio je 2,271 milijardi, što je gotovo udvostručenje u odnosu na razdoblje prije četiri godine, dok je broj stanovnika Kine iznosio 1,391 milijardu stanovnika u 2018. godini (National Dana). Prema izvještaju o korištenju društvenih medija u 2018. u SAD-u, evidentan je porast korištenja u odnosu na prijašnju godinu. Više od 73\% odraslih osoba koriste Youtube, dok 68\% Facebook (Smith and Anderson 2018).

Bez obzira na veliku rasprostranjenost društvenih medija, internet ne može zamijeniti stvarni prijateljski odnos. Stvarno nedjeljno zajedništvo u crkvi ne može zamijeniti online bogoštovlje u udobnosti svoje sobe. Bez obzira na negativnosti koje mogu uzrokovati društveni mediji, profesori s Lemoyne Collegea, Krystine Batcho i Michael S. Broder, slažu se da društveni mediji imaju više pozitivnih strana za društvo od negativnih, navodeći važnost na koji način se vijest 
priopćuje na globalnoj razini kroz socijalne medije. Batcho je rekla da putem društvenih mreža "vi možete trenutno ostvariti društveni kontakt i vezu s ljudima diljem svijeta, s ljudima koji dijele različite svjetonazore, religije, vrijednosti i politiku“ (Graham 2014). Koristeći društvene mreže kao alate za ostvarenje kontakta među ljudima, nudi se mogućnost prijenosa poruke i sadržaja spasenja u Isusu Kristu.

Internet je postao medij kojim se razmjenjuje velik broj informacija u relativno kratkom vremenu. Tomu svjedoči ilustracija o milijunima ljudi koji se diljem svijeta koriste različitim društvenim mrežama putem interneta. Korisnici Youtubea, Googlea, WhatsAppa i Facebooka u jednoj minuti učine gotovo 27 milijuna klikova.

\section{$20188_{\text {Internet Minute }}^{\text {This what }}$}

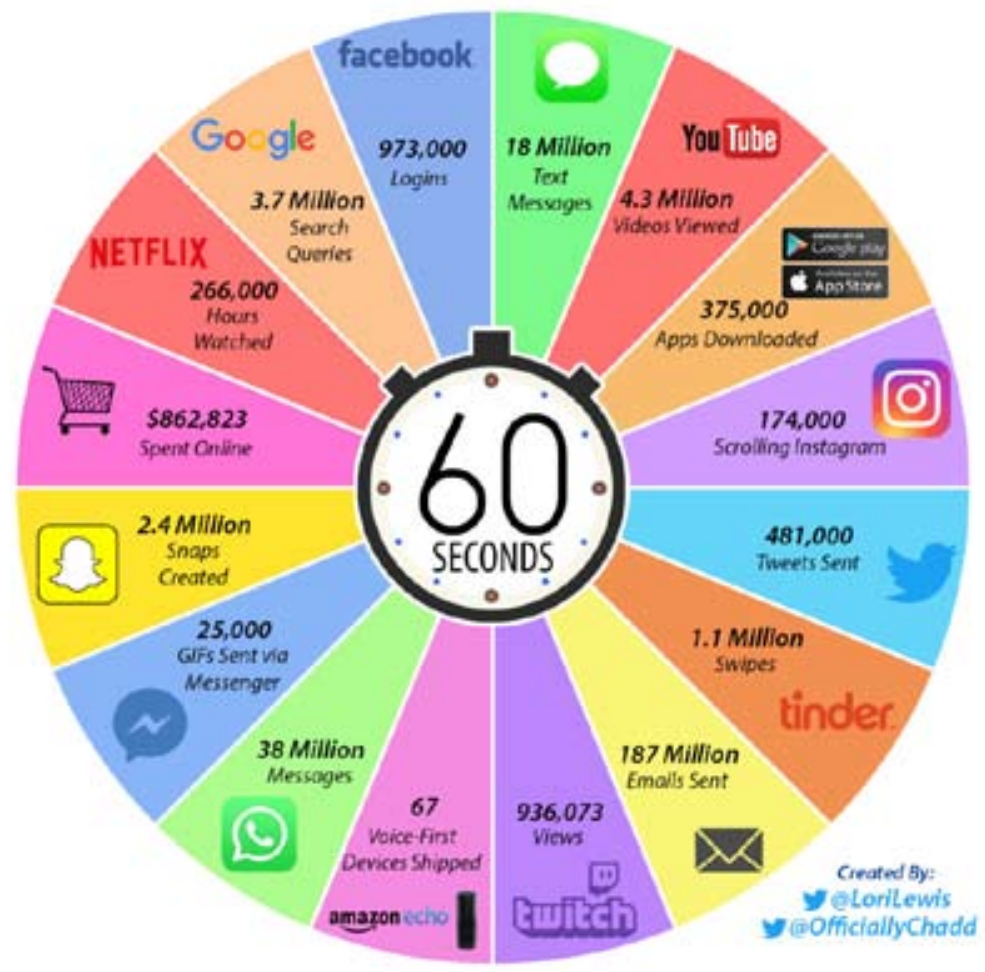

Izvor: Fred Jacob. Wait An Internet Minute 
Svi ovi podaci govore u prilog da su suvremeni mediji u komunikaciji izrazito značajni i u stalnom porastu. Stoga, za Crkvu je značajno da je prisutna u tome Cyber svijetu. Svaka bi mjesna Crkva trebala imati razvijenu informacijsko-komunikacijsku strategiju. Ta bi strategija trebala definirati količinu i razmjenu informacija putem web-stranica, blogova, društvenih mreža, ali isto tako i evangelizacijsko duhovni sadržaj koji bi bio na raspolaganju svim korisnicima. Cilj je razviti takvu strategiju evangelizacije koja će povezati potencijalnog vjernika s Crkvom Kristovom, omogućivši mu da dođe u kontakt s Radosnom viješću i razvije odnos s Kristom i Crkvom u cjelini. Internet i društvene mreže mogu se iskoristiti kao medij pomoću kojeg će povrijeđeni i opterećeni ljudi doći u kontakt s dušobrižnikom koji će ih saslušati i usmjeriti na onoga koji jest „Alfa $i$ Omega, Početak i Svršetak" (Otk 22,13).

Društvene mreže mogu se uspješno koristiti za povećanje ukupne prisutnosti i utjecaja Crkve u svijetu te za usmjeravanje potencijalnih vjernika na zajedništvo u mjesnoj crkvi. Isto tako, ove se mreže mogu koristiti za produbljivanje odnosa postojećih vjernika i njihovo međusobno povezivanje u zajedništvu. Na taj se način mogu okupljati vjernici oko različitih vjerskih programa i projekata te zajednički izgrađivati Crkvu.

Društvene mreže utječu na publicitet i društvenu prepoznatljivost jer generiranje internetskih stranica te prisutnost na društvenim mrežama predstavlja i promovira crkvenu zajednicu širem društvu. Društvene mreže su izvrstan alat povećanja prisutnosti Crkve u njenoj misiji s ciljem širenja radosne vijesti i nebeskoga Kraljevstva na slavu Gospodina. Nekada su kršćani putovali širom svijeta i pronosili Evanđelje u najudaljenije krajeve svijeta. Danas se ta mogućnost pruža svima koji imaju internetsku vezu.

Korištenje suvremenih medija omogućuje stvaranje i održavanje prijateljstava s ljudima širom svijeta. Crkva ne smije biti skrivena unutar četiri zida, već otvorena i prisutna u Cyber svijetu koji razumije današnji svijet. Možda rezultati mukotrpnog rada neće biti odmah vidljivi, ali je potrebno znati da su rezultati u vlasti Gospodina, dok je Crkva pozvana na poslušnost i ustrajnost u dijelima ljubavi. A ljubav pretpostavlja dijalog i komunikaciju.

\section{Analiza upotrebe društvenih mreža u Crkvi}

Istraživanje koje je proveo Paul Steinbrueck (listopad 2014) u kolovozu 2010. godine na uzorku od 193 ispitanika, prikazuje 5 specifičnih prilika koje Crkva može iskoristiti za poboljšanje vlastitog korištenja Facebooka i bolje povezivanje sa svojim članovima. Većina je ispitanika smatrala da njihova crkva ne čini dovoljno u korištenju društvene mreže Facebook. Dok se ti rezultati mogu shvatiti kao negativni, ipak nam otkrivaju velike mogućnosti za Crkvu u korištenju druš- 
tvenih mreža. 39\% ispitanika ocijenilo je korištenje Facebooka u Crkvi kao slab (1 - 3 na skali od 10), 41\% ispitanika ocijenilo je korištenje Facebooka u Crkvi kao osrednji (4 - 7 na skali od 10), a 10\% ispitanika ocijenilo je korištenje Facebooka u Crkvi kao dobar (8 - 10 na skali od 10).

Zaključeno je da prilike koju omogućuje korištenje društvenih mreža su:

1) Veća komunikacija

Rezultati ispitanika su pokazali da većina želi vidjeti svoju Crkvu aktivnijom na Facebooku. 54\% ispitanika naznačilo je da bi željeli vidjeti kako je njihov crkveni post na Facebooku frekventniji, $13 \%$ je naznačilo da bi voljelo da je njihov crkveni post trenutno frekventniji, a samo $1 \%$ je naznačilo da žele da im crkveni post bude rjeđe frekventan.

2) Misijsko-evangelizacijska aktivnost

Druga je mogućnost za crkvene zajednice da individualnom misijskom aktivnosti uključi vjernike kroz Facebook. 87\% ispitanika se slaže ili se jako slaže s izjavom "da bi postali dio crkvene Facebook grupe ako bi i sami bili uključeni u njezin misijski rad"

3) Lako međusobno povezivanje

Treća prilika za crkve je pomoći u međusobnom povezivanju jednih s drugima. 88\% ispitanika izjavilo je da koriste Facebook kako bi ostali u kontaktu s obitelji i prijateljima. Međutim, samo 53\% je reklo da koriste Facebook kako bi ostali u kontaktu s prijateljima iz Crkve i bili obaviješteni o događajima u svojoj mjesnoj crkvi. Jaz između te dvije skupine je $-35 \%$ ispitanika - a to su vjernici koji su povezani s prijateljima na Facebooku, ali ne i s prijateljima iz Crkve.

4) Evangelizacija

Četvrta prilika za crkve je ohrabriti i obučiti vjernike u zajednici da razvijaju odnose s onima koji nisu kršćani i pokažu im Božju milost i ljubav. Samo $45 \%$ ispitanika je izjavilo da radi u tome smjeru.

5) Facebook Ads - oglas

Peta prilika za crkve je korištenje Facebook oglasa da dođu do ljudi u svome društvu. Dok većina ispitanika ne koristi Facebook oglas (ili nije odgovorilo na pitanje), od onih koji ga koriste, $54 \%$ bi preporučilo crkvama korištenje Facebook oglasa, a protiv je bilo samo 7\% ispitanika.

Iz navedenog istraživanja je vidljivo da postoje brojne mogućnosti koje su na raspolaganju vodstvu crkava i vjernicima. Velik broj mjesnih crkava ne koristi webstranice iako one mogu biti oblikovane tako da pruže prihvatljiv sadržaj za sve dobne skupine u zajednici. Uz osnovne podatke o mjesnoj crkvi, stranica može sadržavati kutak za mlade sa zanimljivostima i igrama, kutak za mlade obitelji sa savjetima o odgoju djece te kako prebroditi poteškoće u braku, odabrane teme za mlade, seminare za starije, kršćanske filmove, odabrane propovjedi i sl. Kod 
izrade web-stranice, posebna pažnja se treba posvetiti kvalitetnoj strukturi, sadržaju i ugodnom dizajnu. Isto tako, važno je da domena bude lako pamtljiva te da je stranica optimizirana (SEO). Internet se može koristiti kao marketinški alat da upoznamo i prezentiramo javnosti događanja u Crkvi, njene ideje i planove za budućnost.

Današnje društvene mreže kreirane su za različite segmente korisnika. Facebook je više prijateljska mreža, gdje se razmjenjuju događaji i iskustva iz svakodnevnog života, dok je Linkedin mreža na bazi profesionalnog zanimanja i područja interesa. Chat sobe i forumi su mjesta gdje se mogu iznositi različiti stavovi i debatirati, ali isto tako mogu biti mjestima širenja pozitivizma i nade koja usmjeruju pogled na Krista. Društvene mreže su platforme koje omogućuju razmjenu mišljenja, stavova, slika, priča, događaja, videa, poruka i linkova, a da se pritom odvija dvostruka komunikacija. Društveni mediji pružaju izvanredne mogućnosti za izravnu evangelizaciju. Istraživanje The Social Media Revolution (Qualman 2015) u izdanju iz 2015. godine koristi podatke iz Qualmanove knjige Socialnomics te ističe da:

- 50\% svih ekonomskih trgovanja čine mobilni driveri

- na 1. mjestu po broju populacije je Facebook, 2. Kina, 3. Indija, 4. Tencent, 5. Whatsapp, 6. Google+ 7. Linkedin, 8. USA

- više od 50\% svjetske populacije je ispod 30 godina starosti, što govori u prilog korištenja novih tehnologija u komunikaciji.

Osim računala, koje koristimo za komuniciranje, sve je veća upotreba „pametnih mobitela" koji također mogu biti platforme za naviještanje poruka i sadržaja evangelizacijskog karaktera. Umrežavanjem na društvenim mrežama, stvara se prilika za "proces evangelizacije". Izloženost iste osobe poruci Evanđelja putem različitih komunikacijskih kanala, povećava vjerojatnost predanja osobnog života Kristu i hod u vjeri.

U Evanđelju po Mateju 4, 18-20 Isus je pozvao svoje učenike i rekao im da će ih učiniti „ribarima ljudi“. Dalje nailazimo na redak gdje Isus uspoređuje Kraljevstvo Božje s mrežom u Evanđelju po Mateju 13,47 „Nadalje, Kraljevstvo je nebesko slično velikoj mreži koja se baci u more i zahvati svakovrsne ribe“. Tu mrežu možemo usporediti s današnjim World Wide Webom. Primjer kako koristiti internet u službi evangelizacije vidljiv je na web-stranici organizacije Global Media Outreach (http://gmo.globalmediaoutreach.com/). Web-stranicu je 2004. godine osnovala organizacija Campus Crusade for Christ. GMO ima viziju korištenja interneta, mobilnih uređaja i društvenih mreža u širenju Radosne vijesti o Isusu Kristu širom svijeta među svim stanovnicima na Zemlji s planom evangelizacije svakog pojedinca do 2020. godine. GMO nudi online Bibliju, seminare i edukacije učeništva. Zanimljiva je izjava Walta Wilsona, predsjednika i osnivača GMO-a, bivšega izvršnog direktora Applea. Na iSummitu sveučilišta Biola 2010. je izjavio: 
"Mi smo prva generacija u ljudskoj povijesti koja drži u rukama tehnologiju koja može doći do svakog čovjeka, žene ili djeteta na Zemlji do 2020. godine" (Vu 2010).

Vidljivo je da se taj cilj polako ostvaruje. Wilson je pojasnio da cilj te misije nije samo da se ljudi odluče za Krista online već da nove vjernike učine učenicima te ih povežu s lokalnom Crkvom. Takav primjer može se koristiti i na lokalnoj razini, da mjesna crkva koristeći online pristup sudjeluje u mijenjanju društva i ljudi u društvenoj zajednici u kojem ima učešće u Velikom poslanju Crkve.

Na web-stranici Global Media Outreach je u 2013. prezentirano više od 300 milijuna evangelizacijskih prezentacija, što uključuje stvaranje više od 2 milijuna prezentacija samo u jednom danu. 34 milijuna ljudi donijelo je odluku o prihvaćanju Isusa kao Gospodina i Spasitelja kroz GMO stranice, čime su bili uključeni u proces obraćenja. Iz ovih statističkih podataka može se vidjeti da Bog koristi tehnologiju kako bi došao do izgubljenih koji traže spasenje. Novo misijsko polje danas više ne predstavljaju udaljeni krajevi ovoga svijeta, već domovi ljudi koji žive u neposrednom okruženju, ali i širom svijeta.

\section{Analiza upotrebe interneta i društvenih mreža u mjesnim crkvama reformacijske baštine}

Istraživanje, koje je provedeno 2018. godine ${ }^{1}$, obuhvatilo je članice Protestantsko-evanđeoskog vijeća u Republici Hrvatskoj (https://pev.com.hr/): Kristove crkve (http://kristove-crkve.hr/), Evanđeosku pentekostnu crkvu (http://www.epc. hr/), Savez baptističkih crkava (https://www.baptist.hr/) i Crkvu Božju (https:// crkvabozja.hr/). Provedena je analiza pokazala da svaka vjerska zajednica koristi centralnu web-stanicu s relevantnim podacima. Jedna od članica koristi i Facebook kao društvenu mrežu za razmjenu informacija. Međutim, na lokalnoj razini, vjerske zajednice samo djelomično koriste internet i društvene mreže. Tako od 52 članice Saveza baptističkih crkava u RH, web-stranicu ima dvanaest mjesnih crkava, dok se Facebookom koristi njih dvadeset i dvije. Šest koristi web i Facebook, a kod dvije crkve web-stranice nisu ažurirane. Tako, od ukupnog broja članica, njih 56\% koristi neki oblik nove komunikacije. Od 53 članice Evanđeoske pentekostne crkve u RH, web-stranicu ima sedamnaest mjesnih crkava, dok se Facebookom koristi njih devetnaest. Devet crkava koristi zajedno web i Facebook, dok jedanaest web-stranica nisu ažurirane. Tako, od ukupnog broja članica njih 51\% koristi se novim oblicima komunikacije. Od dvanaest članica Kristovih

1 Istraživanje je proveo Danijel Časni na osnovi analize dostupnih podataka na web-stranicama članica PEV-a te Google pretraživaču u prosincu 2018. 
crkava u RH, web-stranicu imaju četiri mjesne crkve, dok se Facebookom koristi njih osam. Dvije crkve koriste zajedno web i Facebook. Od ukupnog broja članica, $75 \%$ koristi se novim oblicima komunikacije.

Od osam članica Crkve Božje u RH, web i Facebook stranicu ima Crkvena općina u Vinkovcima, na čijim se stranicama nalaze obavijesti i događanja iz svih mjesnih crkvenih općina.

Iz navedenog istraživanja vidljivo je postojanje puno prostora za napredak i razvoj informiranosti o životu i radu mjesne crkve. Kod većih vjerskih zajednica, koje su članice PEV-a, gotovo polovica mjesnih crkvi ne koristi internet ili društvene mreže.

Kao što je internet redefinirao gospodarstvo i poslovanje, isto tako internet će u budućnosti imati značajnu ulogu za Crkvu. Osjeća se potreba stvaranja kvalitetnih online programa za evangelizaciju i učeništvo, što će potaknuti aktivnije uključenje pastora i vjernika. Na raspolaganju su alati, online mreža i sadržaj te je potrebno što više „ribara“ koji će iskoristiti date mogućnosti današnjih društvenih medija kako bi postali „ribarima ljudi“.

Naviještanje Isusa Krista kao Spasitelja treba biti imperativ svakog kršćanina. Krista treba naviještati u današnjem svijetu svima i svagdje. On treba biti prepoznatljiv u svakom istinskom vjerniku. Apostol Pavao je pisao Crkvi u Korintu (1 Kor 15,1-4): „Dozivljem vam, braćo, u pamet, evanđelje koje vam napisah, koje primiste, u kome stojite, po kojem se spasavate, ako držite što sam vam navijestio; osim ako uzalud povjerovaste. Doista, predadoh vam najprije što i primih: Krist umrije za grijehe naše po Pismima; bi pokopan i uskrišen treći dan po Pismima." To je poruka Evanđelja. Tu je poruku potrebno evangelizirati svim ljudima. Da bi se promijenilo društvo, promjena se treba dogoditi u svakom pojedincu. Stoga, internet kao mjesto društvene dinamike može biti iskorišten kao mjesto susreta čovjeka s čovjekom i čovjeka s Bogom.

\section{Zaključak}

Internet, kao medij današnjice, prisutan je među svim generacijama. Njegovim korištenjem Crkvi se otvaraju nove mogućnosti u naviještanju Evanđelja Gospodina Isusa Krista u današnjem globaliziranom svijetu masovnih medija, interneta i društvenih mreža. S obzirom na to da je broj korisnika novih medija u stalnom porastu, korištenje suvremenih komunikacijskih kanala u navješćivanju Radosne vijesti ima za cilj doprijeti do ljudi koji traže smisao života i uputiti ih na spasenje u Kristu koje ima vječnu vrijednost. Društvene mreže odlikuje dvostrana komunikacija te je online prisutnost Crkve u digitalnom svijetu od iznimne važnosti. Društveni medij može biti učinkovita platforma za evangelizaciju, informiranje o događanjima u Crkvi te alat za razvijanje odnosa između vjernika međusobno 
i s društvom u kojem djeluju. Generiranjem crkvene internetske stranice te prisutnošću na društvenoj mreži, crkvena zajednica i njene aktivnosti predstavljaju se i promoviraju širem društvu, a njezin evangelizacijski sadržaj može potaknuti pojedinca na susret s Kristom. Situacijska analiza vjerskih zajednica u Republici Hrvatskoj, koje su članice PEV-a, pokazala je kako nisu dovoljno iskorištene mogućnosti interneta i društvenih mreža. Sukladno tomu, postoji mnogo prostora za napredak i razvoj novih medija u životu i radu mjesne crkve.

Za evangelizaciju na raspolaganju su alati, online mreža i spasonosni sadržaj te je potrebno što više „ribara“ koji će iskoristiti mogućnosti današnjih društvenih medija kako bi postali „ribarima ljudi“.

\section{Literatura}

Cavazza, Frédéric. Juny 2008. Social media Landscape. FredCavazza.net. http:// www.fredcavazza.net/2008/06/09/social-media-landscape/ (preuzeto 24.01.2019).

Eurostat. July 2018. EU population up to nearly 513 million on 1 January 2018. European Commision. https://ec.europa.eu/eurostat/ documents/2995521/9063738/3-10072018-BP-EN.pdf/ccdfc838-d909-4fd8-b3f9-db0d65ea457f (preuzeto 11.02.2019.)

Evangelizacija. 1997. Zagreb. BGEA \& Duhovna Stvarnost.

Facebook. January 2015. Facebook Reports Fourth Quarter and Full Year 2014 Results. Investor Relations. https://investor.fb.com/default. aspx?SectionId $=5$ cc5ecae-6c48-4521-a1ad-480e593e4835\&LanguageId $=1 \&$ PressReleaseId=71fc9f6a-4565-41e4-a5eb-793fad537598 (preuzeto 11.02.2019.)

Green, Michael. 1979. Evangelizacija sada i onda. Osijek. Izvori.

Graham F., Regina. April 16. 2014. Psychologist: Social Media Causing A 'Distancing Phenomena' To Take Place. DBS Broadcasting, https://washington. cbslocal.com/2014/04/16/psychologist-social-media-causing-a-distancingphenomena-to-take-place/ (preuzeto 24.01.2019.)

Jacob, Fred. April 9, 2018. Wait An Internet Minute! Jacobs Media strategies. https://jacobsmedia.com/wait-internet-minute/ (Preuzeto 23.01.2019.)

Maletić, Franjo. 2008. „Informacijsko modeliranje razvoja novinske industrije u digitalnoj eri“. Doktorska disertacija. Filozofski fakultet sveučilišta u Zagrebu.

National Data. National Bureau of Statistics of China. http://data.stats.gov.cn/ english/ (preuzeto 23.01.2019) 
Qualman, Eric. January 2015. Social Meda Revolution 2015. Youtube. https:// www.youtube.com/watch? $\mathrm{v}=$ jottDMuLesU (preuzeto 24.01.19.)

Smith, Aaron i Anderson, Monica. March 2018. Social Media Use in 2018. Pew Research Center. http://www.pewinternet.org/2018/03/01/social-mediause-in-2018/ (preuzeto 24.01.2019.)

Statistica. 2018. Number of monthly active Facebook users worldwide as of 3 rd quarter 2018 (in millions), The Statistics Portal. https://www.statista.com/ statistics/264810/number-of-monthly-active-facebook-users-worldwide/ (preuzeto 23.01.2019.)

Steinbrueck, Paul. October 2014. Church Social Media Survey Reveals a Striking Contradiction. Our Church Com. http://blog.ourchurch.com/2014/10/28/ church-social-media-survey-reveals-a-striking-contradiction/ (preuzeto 24.01.2019).

Stenovec, Timothy. January 2015. Facebook Is Now Bigger Than The Largest Country On Earth. Huffpost. http://www.huffingtonpost.com/2015/01/28/ facebook-biggest-country_n_6565428.html, (preuzeto 24.01.2019).

Vu, A. Michelle. April 2010. GMO: Potential There to Reach World with Gospel by 2020. The Christian Post. https://www.christianpost.com/news/gmopotential-there-to-reach-whole-world-by-2020.html (preuzeto 24.01.2019).

\author{
Danijel Časni
}

\title{
The Need and Possibility for Evangelizing Through the Internet
}

\begin{abstract}
In today's society of technological advancement, evangelizing through the Internet is an adequate tool for proclaiming the Good News. By using the Internet, the Church communicates on a local level to its local church but also on a broader scale at the global level, thus fulfilling its mission of proclaiming the Gospel "to all the nations." The paper talks about the need of using the Internet and social networks for evangelism, as a medium for communicating the message of salvation and hope in Jesus Christ. By analyzing the usage of the Internet in Evangelical churches in Croatia we gain an insight into the current condition and the possibility of a more efficient way of using the new media in proclaiming the Good News.
\end{abstract}

